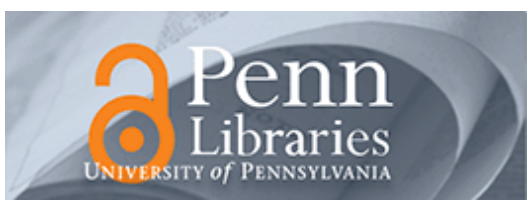

University of Pennsylvania ScholarlyCommons

1992

\title{
Jewish Thought in Newtonian England: The Career and Writings of David Nieto (In Memory of Jacob J. Petuchowski)
}

David B. Ruderman

University of Pennsylvania, RUDERMAN@SAS.UPENN.EDU

Follow this and additional works at: http://repository.upenn.edu/history_papers

Part of the Cultural History Commons, History of Religion Commons, Intellectual History Commons, Jewish Studies Commons, and the Religious Thought, Theology and Philosophy of $\underline{\text { Religion Commons }}$

\section{Recommended Citation}

Ruderman, D. B. (1992). Jewish Thought in Newtonian England: The Career and Writings of David Nieto (In Memory of Jacob J. Petuchowski). Proceedings of the American Academy for Jewish Research, 58 193-219. http://dx.doi.org/10.2307/3622633 


\title{
Jewish Thought in Newtonian England: The Career and Writings of David Nieto (In Memory of Jacob J. Petuchowski)
}

\begin{abstract}
David Nieto (1654-1728), the first rabbi of the new Bevis Marks Synagogue and the hakham of the Spanish and Portuguese congregation of London at the beginning of the eighteenth century, is not an unstudied figure in recent Jewish historiography. From the early portrait of Moses Gaster to the later elaborations of Cecil Roth and Moses Hyamson, and from the exhaustive bibliographical study of Israel Solomons to the pioneering study of Nieto's thought by Jacob Petuchowski, Nieto's public career and theological writings have been examined as well as any other Jewish intellectual figure of early modern Europe. ${ }^{1}$ Yet each of these studies, especially Petuchowski's book, was completed over thirty years ago. In the interim, new scholarship in Jewish history, particularly in the history of Marranism and Sabbatianism, has illumined the broader cultural ambiance of Nieto's era. ${ }^{2}$

\section{Disciplines}

Cultural History | History | History of Religion | Intellectual History |Jewish Studies | Religious Thought, Theology and Philosophy of Religion
\end{abstract}

\section{Comments}

At the time of this publication, Dr. Ruderman was affiliated with Yale University, but he is now a faculty member of the University of Pennsylvania. 


\title{
JEWISH THOUGHT IN NEWTONIAN ENGLAND: THE CAREER AND WRITINGS OF DAVID NIETO*
}

(In Memory of Jacob J. Petuchowski)

\author{
BY DAVID B. RUDERMAN
}

David Nieto (1654-1728), the first rabbi of the new Bevis Marks Synagogue and the hakham of the Spanish and Portuguese congregation of London at the beginning of the eighteenth century, is not an unstudied figure in recent Jewish historiography. From the early portrait of Moses Gaster to the later elaborations of Cecil Roth and Moses Hyamson, and from the exhaustive bibliographical study of Israel Solomons to the pioneering study of Nieto's thought by Jacob Petuchowski, Nieto's public career and theological writings have been examined as well as any other Jewish intellectual figure of early modern Europe. ${ }^{1}$ Yet each of these studies, especially Petuchowski's book, was completed over thirty years ago. In the interim, new scholarship in

* My thanks to Professor Michael Heyd, Moshe Idel, Yosef Kaplan, and Robert Bonfil for reading an earlier draft of this essay and for their critical comments. An earlier version of this essay was presented as a paper at the annual meeting of the Association for Jewish Studies in December, 1990.

${ }^{1}$ M. Gaster, History of the Ancient Synagogue of the Spanish and Portuguese Jews (London, 1901); pp. 101-16; C. Roth, Essays and Portraits in Anglo-Jewish History (Philadelphia, 1962), pp. 113-129 [Hebrew version of same essay is part of introduction of edition of Ha-Kuzari haSheni Hu Matteh Dan, ed. J.L. Maimon, (Jerusalem, 1958)]; A. Hyamson, The Sephardim of England (London, 1951), index;' I. Solomons, "David Nieto and Some of his Contemporaries," Transactions of the Jewish Historical Society of England 12 (1931): 1-101; J.J. Petuchowski, The 
Jewish history, particularly in the history of Marranism and Sabbatianism, has illumined the broader cultural ambiance of Nieto's era. ${ }^{2}$ Even more dramatic has been the plethora of scholarship on English political and cultural history, and especially the history of scientific thought. ${ }^{3}$ In the light of new insights offered by both scholarly literatures, Nieto's

Theology of Haham David Nieto: An Eighteenth-Century Defense of the Jewish Tradition (New York, 1954, 1970).

${ }^{2}$ I refer especially to G. Scholem's many studies, first and foremost, his book, Sabbatai Sevi: The Mystical Messiah (Princeton, New Jersey, 1973); the various essays of J. Leibes on Sabbatianism, especially his "The Ideological Basis of the Polemic over Hayon (Hebrew)," Proceedings of the Eighth World Congress of Jewish Studies (Jerusalem, 1982), Unit II, pp. 129-134; and his "Sabbatian Messianism (Hebrew)," Pe'amim 40 (1989): 4-20; E. Carlebach, The Pursuit of Heresy: Rabbi Moses Hagiz and the Sabbatian Controversies (New York, 1990); the many essays and books of M. Benayahu and I. Tishby on Sabbatianism; Y. Yerushalmi, From Spanish Court to Italian Ghetto (New York, 1971; Seattle and London, 1981); J. Kaplan, Mi-Nazrut le-Yahadut: Hayav u-Fo'olo Shel ha-Anu$s$ Yizhak Orobio De Castro (Jerusalem, 1983; English translation, OxfordNew York, 1989); N. Yosha, "The Philosophical Elements in the Doctrine of God of Abraham Migual Cardoso," (Hebrew), M.A. Dissertation, Hebrew University, 1985; idem, "The Philosophical Background of Sabbatian Theology - Guidelines towards an Understanding of Abraham Michael Cardoso's Theory of the Divine (Hebrew)," in Galut Ahar Golah: Mehkarim be-Toledot Am Yisra'el Mugashim le-Professor Haim Beinart, eds. A. Mirsky, A. Grossman, Y. Kaplan (Jerusalem, 1988), pp. 541-73; D. Katz, Philosemitism and the Readmission of the Jews into England, 1603-1655 (Oxford-New York, 1982); J. Israel, European Jewry in the Age of Mercantilism 1550-1750 (Oxford-New York, 1985), and much more.

${ }^{3}$ The literature is too vast to cite here. A recent overview which stresses the connection between political and scientific culture in early modern Europe is M.C. Jacob, The Cultural Meaning of the Scientific Revolution (Philadelphia, 1988), including a useful bibliographical essay. This should be compared with C. Russell, Science and Social Change in Britain and Europe 1700-1900 (New York, 1983), and M. Hunter, Science and Society in Restoration England (Cambridge, 1981), with its useful bibliographical essay, recently updated in his Establishing the New Science: The Experience of the Early Royal Society (Woodbridge, England, 
career and intellectual achievements require a fresh look, particularly because Nieto's “Jewish" preoccupations were so closely intertwined with the larger cultural concerns of his newly adopted country.

David Nieto came to England in 1701 to assume the chief rabbinic post of the fledgling community of Jews of Sephardic descent, primarily former conversos. Since his contract stipulated that he could not practice medicine, despite the prestigious medical degree he held from the University of Padua, ${ }^{4}$ he fully understood his new calling as that of a public figure, the chief representative of his co-religionists in England, and their primary spokesman and religious leader. His primary concern was to be the welfare of his community, its legal status, its economic and social condition, as well as its spiritual well-being. At the same time, Nieto was more than a public official and religious functionary. In inviting him to England, the Sephardim had engaged one of the most original minds of eighteenth century Jewry, a prolific writer in Hebrew and Spanish, well educated in Jewish and secular subjects. Like other illustrious Jewish intellectuals of his era, especially those of Italian provenance, he had studied medicine and rabbinics, and had pursued simultaneously a rabbinic and medical career while in Italy. ${ }^{5}$ Upon his arrival in England, he already held a reputation as a serious scholar of

1989), pp. 356-68. Other works consulted especially for this essay, dealing specifically with England, are listed in the notes below.

${ }^{4}$ See Solomons, p. 8.

${ }^{5}$ Cf. D.B. Ruderman, "The Impact of Science on Jewish Culture and Society in Venice (With Special Reference to Graduates of Padua's Medical School), Gli Ebrei e Venezia secoli XIV-XVIII, ed. G. Cozzi (Milan, 1987), pp. 417-48, 540-42; idem, Science, Medicine, and Jewish Culture in Early Modern Europe, Spiegel Lecture in European Jewish History (Tel Aviv, 1987); idem, Kabbalah, Magic, and Science: The Cultural Universe of a Sixteenth-Century Jewish Physician (Cambridge, Mass., 1988); idem, "The Language of Science as the Language of Faith: An Aspect of Italian Jewish Thought in the 17th and 18th Centuries," Festschrift in Honor of Shlomo Simonsohn, forthcoming. 
Judaism, and was well versed in the sciences and in several European languages as his correspondence with Theopold Unger and other Christian intellectuals patently indicates. ${ }^{6}$ Although he was apparently insecure about his inability to speak and write fluent English, ${ }^{7}$ he was certainly able to hold his own among his new countrymen as an expositor of Judaism in an era of formidable intellectual challenges. To appreciate fully Nieto's place in the history of Jewish civilization, we must consider both of his faces - the political as well as the intellectual - and particularly how they intersected throughout his distinguished career on English soil.

As his writings so readily testify, he considered the profound impact of the sciences on European culture and society a supreme intellectual challenge to the viability of Judaism at the turn of the century. In England, especially, Nieto encountered a highly sophisticated society of scientists and churchmen who had creatively wedded the new advances in science to their own political and religious aspirations. These "virtuosi" had found in the new scientific discoveries a potent vehicle in which to enhance their understanding of the Christian faith. ${ }^{8}$ In early

${ }^{6}$ Cf. Solomons, pp. 21-24, 38-44.

${ }^{7}$ In a letter to Dr. John Covel, the Master of Christ's Church, Cambridge, written in 1705-6, Nieto claimed he could not write English. See Solomons, p. 22.

${ }^{8}$ See especially, R. Merton, Science, Technology and Society in Seventeenth-Century England (New York, 1970); C. Webster, The Great Instauration: Science, Medicine, and Reform (London, 1975); idem, ed., The Intellectual Revolution of the Seventeenth Century (London and Boston, 1974); C. Hill, The Intellectual Origins of the English Revolution (Oxford, 1965); J. Jacob, "Restoration, Reformation, and the Origins of the Royal Society," History of Science 13 (1975): 155-176; R.S. Westfall, Science and Religion in Seventeenth-Century England (New Haven, 1958); J. Jacob and M. Jacob, "The Anglican Origins of Modern Science," Isis 71 (1980): 251-67; M. Jacob, The Newtonians and the English Revolution (Ithaca, New York, 1976). Compare, however, the works by Russell and Hunter mentioned in note 3 above; L. Mulligan, "Puritans and English Science: A Critique of Webster," Isis 71 (1980): 456-69; , nd see the additional references in the following footnote. 
modern Europe, and particularly in England, as Margaret Jacob and others have argued, ideas about the natural world often bore a direct relation to the way people understood the social and moral order. ${ }^{9}$ In the seventeenth century, such thinkers as Hobbes and Spinoza had articulated mechanical or pantheistic philosophies of nature which assumed that nature, not God, was a sufficient explanation for the cause and workings of the material environment. Among such "heretics", a philosophy of pantheistic materialism, claiming that God could only be located within natural objects, could readily serve as a philosophical justification for democratic belief. Since all things in nature shared a sense of divinity, all were ostensibly equal. The ways of nature militated against all social and political hierarchies and called for a total social levelling and a radical dismemberment of political power and privilege. Such philosophies of nature were accordingly deemed dangerous to those responsible for perpetuating the social order. They not only undermined traditional Christian orthodoxies; they also challenged the self-interest and stable polity of governments which fostered religious ideologies and behavior that might

${ }^{9}$ This is a central point of Jacob's book referred to in the previous note, whose influence on the writing of this essay is apparent. See also her essay "Christianity and the Newtonian World View" in God and Nature: Historical Essays on the Encounter Between Christianity and Science (Berkeley and Los Angeles, 1986), pp. 238-255, The Cultural Meaning of the Scientific Revolution, pp. 73-135; and P.M. Heimann, "Science and the English Enlightenment," History of Science 16 (1978): 143-51. Her work, nevertheless, has evoked a considerable degree of criticism and refinement regarding her oversimplification of Newtonianism and her neglect of orthodox hostility to the latter. See, for example, the works of Hunter and Russell, especially chap. 4; J. Force, William Whiston, Honest Newtonian (Cambridge, 1985); G. Holmes, "Science, Reason, and Religion in the Age of Newton," British Journal for the History of Science 12 (1979): 164-71; C.B. Wilde, "Hutchinsonian Natural Philosophy and Religious Controversy in Eighteenth Century Britain," History of Science 18 (1980): 1-24; and A. Guerrini, "The Tory Newtonians: Gregory Pitcaire and their Circle," Journal of British Studies 25 (1986): 288-311. 
buttress the political foundations of their Protestant kingdoms. ${ }^{10}$

In opposition to these heretics stood the Christian Anglican proponents of the new science. They became especially prominent in England after the revolution of 1688-89, and were at the height of their power and influence during Nieto's career in London in the first decades of the eighteenth century. Their heros were Boyle and Newton whom they lionized as the architects of a new Christian vision of the universe stamped with the seal of the Divinity. They defined the basis of their Christian faith as a natural religion or natural theology that glorified the new science while repudiating the outmoded Aristotelianism of the universities and the mechanical philosophies of Hobbes and Descartes with their materialistic and potentially atheistic implications. They were equally disdainful of the newest version of pantheism made prominent by the political radical John Toland. In their place, they proposed a mechanical philosophy requiring God's active engagement in the workings of nature. The new discoveries revealed more distinctly than ever the manifold glimpses of the divine presence in everything. Science insured a faith in traditional Christian truths, so they argued, and also provided the most effective underpinning for their vision of a stable and prosperous social order ruled by human self-interest but controlled and

${ }^{10}$ See especially, P. Hazard, The European Mind (New Haven, 1953); C. Hill, The World Turned Upside Down (New York, 1972); M. Jacob, The Radical Enlightenment: Pantheists, Freemasons, and Republicans (London and Boston, 1981); C. Giuntini, Pantheismo e ideologia republicana: John Toland (1670-1722) (Bologna, 1979); R. Kargon, Atomism in England from Harriot to Newton (Oxford, 1966); R. Colie, "Spinoza in England 1665-1730," Proceedings of the American Philosophical Society 107 (1963): 183-219; S.I. Mintz, The Hunting of Leviathan (Cambridge, 1962); Hunter, Science and Society, chap. 7; idem, "Science and Heterodoxy," in R.S. Westman and D.C. Lindberg, eds., Reappraisals of the Scientific Revolution (Cambridge, 1990); R.E. Sullivan, John Toland and the Deist Controversy: A Study in Adaptations (Cambridge, Ma. and London, 1982). 
directed by religious moderation and good taste. If the scientists had unveiled a blueprint of the harmony and stability operating in nature, it could and should be correlated with the proper workings of the social and economic order. Order in nature prescribed social and political stability in the world of government, church hierarchies, and capitalist markets. ${ }^{11}$

This new vision of Anglican Latitudinarian religiosity that nurtured stability and harmony in the natural and social realms, balancing the pursuit of self-interest with religious and political duty, was ultimately bound to clash with all forms of radicalism - religious, political, and economic. The spokesmen of this new orthodoxy saw as their primary purpose the defeat of all atheists, deists, freethinkers, and enthusiasts, who were often lumped together, as the primary enemies of religion and the state. Uncontrolled extremism in the religious realm deemed pejoratively as religious enthusiasm, was viewed as a critical threat to ecclesiastical power and as an illegitimate religious sensibility that might undermine their carefully calibrated sense of balance and order within the church, the political realm, and the marketplace. ${ }^{12}$

The most prominent platform for disseminating this new vision of Anglican Christianity confirmed by science was the prestigious Boyle lectures, established with income from the estate of Robert Boyle and held annually from 1692 to 1714.

11 These themes are developed by Jacob in The Newtonians and the English Revolution. See as well the other works cited in notes 8 and 9.

12 On the attacks against enthusiasm, see G. Williamson, "The Restoration Revolt against Enthusiasm," Studies in Philology 30 (1935): 571-604 [reprinted in his Seventeenth Century Contexts (London, 1960), pp. 202-39]; P.B. Wood, "Methodology and Apologetics: Thomas Sprat's History of the Royal Society," The British Journal for the History of Science 13, 43 (1980): 1-26; M. Heyd, "The Reaction to Enthusiasm in the Seventeenth Century: Towards an Integrative Approach," Journal of Modern History 53 (1981): 258-80; idem, "The New Experimental Philosophy: A Manifestation of 'Enthusiasm' or an Antidote to It?" Minerva 25 (1987): 423-40; idem, "Be Sober and Reasonable": Science, Medicine, and the Critique of Enthusiasm in the Seventeenth and Early Eighteenth Centuries, forthcoming. 
The lectures offer an extraordinary index of official Anglican theology confirmed with the seal of approval of the scientific and political establishment. Among the most prominent of the Boyle lecturers was Samuel Clarke whose erudite addresses on the being and attributes of God of 1704 and the obligations of the Natural Religion and the certainty of the Christian revelation of 1705 encapsulate quite effectively the essence of the new theological fusion between Christianity and Newtonian science. These lectures in particular bear an uncanny resemblance to Nieto's own theological writings, as we shall soon observe. ${ }^{13}$

David Nieto's intellectual and political consciousness appears to be shaped by this ideology so forcefully articulated by the Anglican religious establishment. Nieto's vision of traditional Judaism as formulated in his highly polemical writings can only be fully appreciated by comparing it with that of his Anglican colleagues. From the time of his first publication in London until his death, he creatively adapted positions and theological solutions paralleling their own in the cause of traditional Judaism. Having only stepped off the boat as a new immigrant several months earlier, he composed in Spanish in December of 1701 a prayer which begins: "A fervid and humble prayer addressed to the Great and Omnipotent God of Israel by the Congregation of Jews in London, in which they implore the assistance and help of Heaven at the Deliberations of His

${ }^{13}$ The Boyle lectures are treated in Jacob, The Newtonians and the English Revolution, chaps. 4 and 5. See also J. Dahm, "Science and Apologetics in the Early Boyle Lectures," Church History 39 (1970): 172-86. Hunter's argument that the lectures were neither homogeneous nor focused exclusively on Newtonian science is an important corrective to Jacob's treatment. See his works cited in note 3 and those cited in note 9, especially James Force's study of Clarke's colleague Whiston. On Clarke, compare J.P. Ferguson, An Eighteenth Century Heretic Dr. Samuel Clarke (Kineton, 1976), and L. Stewart, "Samuel Clarke, Newtonianism, and the Factions of Post-Revolutionary England," Journal of the History of Ideas 42 (1981): 53-72. I have read Clarke's two sermons in Samuel Clarke, The Works 1738 in Four Volumes (Garland Reprint, New York and London, 1978), vol. 2, pp. 513-733. 
Majesty the Invincible King William III, their sovereign, of his Supreme Council, and of both the Chambers of his August Parliament." ${ }^{14}$ An encomium to the political establishment was certainly consistent with other forms of political flattery in which Jewish leaders had indulged for centuries. But Nieto's prayer, when viewed together with his elaborate discussion of Judaism and the sciences, his ruminations on God and nature, his polemics with the Sabbatian enthusiast Nehemiah Hiyya Hayon, and the general direction of his public and literary career, suggest repeatedly a consistent and distinctive ideological position unmistakably reminiscent of the image of his Anglican counterparts. Nieto quickly learned that Judaism could only survive within English society by both demonstrating the constant political loyalty of Jewish immigrants to the Crown and to the leadership elite as well as by appropriating the conceptual language and ideological underpinnings of its religious establishment. English Jews would remain Jews, so Nieto believed, if their religious aspirations and sensibilities would be in tune with both their economic and social aspirations and with those of their Christian neighbors. To these objectives he devoted his most creative energies.

It is difficult to point to any single source for Nieto's primary inspiration. The fonts of his literary imagination were still located in traditional Jewish sources; he was especially indebted to Judah ha-Levi's great classic and its dialogical form in the writing of his largest work, the Mateh Dan. But surely Jewish texts alone could not account for the strategies he now employed in defense of his ancestral faith. If any contemporary source of inspiration comes closest to expressing Nieto's most characteristic lines of argument, it is the famous lectures of Dr. Samuel Clarke, the Boyle lecturer of 1704-05. We shall examine the possibility of a relationship between the two authors below. Whatever the relationship, if any, it is clear that Nieto's positions paralleled those of Clarke and his Newtonian circle

14 See Solomons, p. 8. 
and that all of Nieto's major writings reveal in their totality a conscious and creative response of their author to his cultural environment. All three works display unambiguously the ability of a Jewish thinker to absorb the dominant theological positions of his Christian contemporaries and to reformulate them as Jewish theology before a recently constituted congregation of assimilated, secularized, highly ambitious but politically and culturally insecure Jewish merchants.

Nieto's first major work was his De La Divina Providencia published in London in 1704. Written in his preferred dialogical form in the wake of a controversy which had seriously threatened his good name and still brief tenure as religious leader, it was meant to clarify Nieto's position on divine providence and its relation to nature. Having delivered a sermon on November 20,1703 on the same topic, some of his listeners were alarmed to hear that the hakham had identified nature with God. One member of the congregation, Joshua Zarfatti, petitioned the congregation to condemn their religious leader for being a heretic. A long controversy ensued involving several members of the London congregation, the Attorney-General, and eventually Hakham Zevi Ashkenazi of Amsterdam. ${ }^{15}$ While the details of the controversy have been discussed before, the precise context of the debate and Nieto's published work have yet to be fully clarified. Most interpreters of the debate have understood the alarm of Nieto's detractors as merely stemming from their belief that he was a Spinozist. While Spinoza is

15 The work and the controversy are discussed in Solomons, pp. 10-17 as well as in the other works mentioned in note 1 above. See also A. Barzel, “General Nature and Particular Nature (Hebrew)," Da'at 17 (1986): 67-80. I have used the original Spanish edition published by James Dover as well as the English translation of E.H. Lindo of 1853, listed as Codex Adler (6c), in Solomons, p. 66, and now located in the library of the Hebrew Union CollegeJewish Institute of Religion in Cincinnati. My thanks to the latter institution for providing me a copy of this manuscript. 
nowhere mentioned explicitly in either Nieto's summary of the sermon or in his more lengthy dialogue, scholars assumed that the allegations of heresy were Spinozist even though Nieto's thoughts were obviously misconstrued. If fact, Spinoza's pantheistic ideas were well known in England by the early eighteenth century and may have certainly been familiar to some of Nieto's accusators. ${ }^{16}$ But pantheism as a religious philosophy was certainly a broader phenomenon than Spinoza's ideas and clearly could have suggested wider associations for Nieto's listeners.

To appreciate fully Nieto's reflections on divine providence and the acrimony they elicited, we should mention not one but three distinct views. First, was the view which Nieto's enemies thought they heard their hakham express, namely, his alleged pantheism. The first stirrings of pantheism, also known as materialism, in England were among sectarian radicals in the 1650s and later among Whig circles after the revolution of 1688. The most prominent pantheist in Nieto's day was John Toland who had proclaimed nature, not God, as the sole object of worship and study. The origins of this ideology could be traced to certain magical and naturalistic views of the Renaissance, and only later was it merged with Hobbesian materialism and Spinozist tendencies. In fact, Toland himself was the first to equate pantheism and Spinozism as late as 1709. As a challenge to the dualist nature of Christian metaphysics, and specifically the transcendent nature of God, it was troublesome enough as a religious philosophy. As the foundation for a political philosophy that preached social equality for all since God is in all nature and all natural things are equal, it clearly resonated with dangerous social implications for those who staked their own existence on the preservation of the existing social order. ${ }^{17}$

But Nieto had no sympathy for pantheism nor did he intend to discuss it in his sermon. Rather, he presented another view

16 See the essay by $R$. Colie in note 10 .

17 For references, see note 10 above. 
which he found most objectionable. At the opening of the first dialogue of De La Divina Providencia, Nieto spells out this position through the mouthpiece of Simon. Simon claims that God gave nature the faculty and power to govern the world, arranging the whole in so fixed and inalterable a manner while reserving occasionally the possible intervention of miracles for himself. ${ }^{18}$ Simon marshals a number of biblical and rabbinic quotations to confirm this idea, including the rabbinic statement: "The world follows its course." ${ }^{19}$ When Reuven, Simon's interlocuter, presents Nieto's position that God and nature are the same, Simon parries with two primary objections to the latter. He claims that if God and nature are one, all creatures are then identical with God. Moreover, if God performs all that nature does, there is no place for the miraculous. Accordingly, the natural should come from nature; the miraculous from God. $^{20}$

What follows is a sustained critique of Simon's position by Reuven. At one point, Reuven even identifies Simon's position with that of the deists "who believed that there was only one God but He didn't trouble himself in the government of the world. They say that nature directs [this machine] and governs everything in its way ... that God left the power of governing the world to a supposed universal nature as a prince who leaves the government to his minister." ${ }^{21}$ Reuven concludes that this is enormous heresy and blasphemy; instead, only God governs the world.

To whom was Nieto referring when presenting Simon's view? He might have had in mind the views of Henry More and Ralph Cudworth, the two most prominent Cambridge Platonists, as well as John Ray, the famous "virtuoso", regarding the idea

${ }^{18}$ De La Divina Providencia, pp. 2-3; On Divine Providence, pp. 9-11.

${ }^{19}$ B.T. Avodah Zarah 54b and elsewhere.

${ }^{20}$ De La Divina Providencia, pp. 4-5; On Divine Providence, pp. 11-12.

${ }^{21}$ De La Divina Providencia, p. 9; On Divine Providence, p. 17. Compare Russell, Science and Social Change, pp. 45-46. 
known as "plastic nature". Clearly opposed to the mechanistic and pantheistic views of nature which denied God any will at all, they settled instead for a notion that likened nature to a kind of semi-deity, lieutenant, or viceregent of God, providing Him an instrument through which $\mathrm{He}$ could govern the universe and intervene when necessary to perform miracles. By assigning general nature the responsibility for regularly governing the world, they absolved God of the responsibility of evil. ${ }^{22}$ Robert Boyle objected strenuously to this notion of plastic nature and consistently maintained that the universal and benevolent order of nature was identical with divine providence. ${ }^{23}$ Samuel Clarke, his disciple and later disseminator of his views, identified this notion with a kind of deism and maintained that it unavoidably leads to absolute atheism..$^{24}$

It is the third view, the view of Reuven, with which Nieto identifies and which is brought by him to counter the allegedly pernicious view of Simon, which, like Clarke, Nieto understands as deism, heresy, blasphemy, and "absolute atheism". It

${ }^{22}$ On the notion of plastic nature, see, for example, the following statement of Ralph Cudworth: "Since neither all things are produced fortuitously, or by the unguided mechanism of matter, nor God himself may reasonably be thought to do all things immediately and miraculously; it may well be concluded, that there is a plastic nature under him, as an inferior and subordinate instrument, doth drudgingly execute that part of his providence, which consists in the regular and orderly motion of matter," The True Intellectual System of the Universe, ed. J.L. Mosheim, trans. J. Harrison (London, 1845, originally published 1678), I, pp. 223-24 [quoted in Hunter, Science and Society, pp. 18182]. See also Westfall, Science and Religion, pp. 84-85, 94-95; Colie, p. 197, and idem, Light and Enlightenment: $A$ Study of the Cambridge Platonists and the Dutch Arminians (Cambridge, 1957), chap. 7; Mintz, The Hunting of Leviathan, chap. 5; Hunter, Science and Society, pp. 181-82; R.A. Green, "Henry More and Robert Boyle on the Spirit of Nature," Journal of the History of Ideas 23 (1962): 451-74.

${ }^{23}$ Colie, p. 197; J.E. McGuire, "Boyle's Conception of Nature," Journal of the History of Ideas 33 (1972): 523-42; Heimann, "Science and the English Enlightenment," pp. 145-46.

${ }^{24}$ Clarke, Works, pp. 600-602. 
is this third view which is the centerpiece of his sermon and treatise and to which all his energy is directed, and it is this view which is badly misinterpreted as pantheism by his detractors when in reality he meant something else entirely. A close reading of Samuel Clarke's sermon on the obligations of the natural religion published almost at the same time as Nieto's treatise makes the rabbi's position perfectly unambiguous. $^{25}$

Clarke's long discourse had carefully delineated the various kinds of deism that undermined the true Christian faith. The view Nieto had identified with that of Simon was the first Clarke discussed. ${ }^{26}$ Upon declaring this position to be atheistic, Clarke maintained that creation depended on God's continual power upon it, [quoting Matthew] "with whom not a sparrow falls to the ground and with whom the very hairs of our head are all numbered." A world left to its own resources to form "a world of adventures", is nothing more than a philosophical vanity for Clarke. On the contrary, everything in the universe displays the marks of the Creator "that from the brightest star in the firmament of heaven, to the meanest pebble on the face of the earth, there is no one piece of matter which does not afford such instances of admirable artifice and exact proportion and contrivance, as exceeds all the wit of man." 27

Such pious sentiments about divine providence were a commonplace among English "virtuosi" of the seventeenth century but Clarke's sermon specifically makes those points of particular importance to Nieto. In response to the argument that reserves the ordinary for nature and the miraculous for God, Clarke emphatically denies that the distinction between the natural and the miraculous is meaningful. It is in God's power to do everything equally well. Thus either nothing should

${ }^{25}$ Ibid., pp. 581-733.

${ }^{26}$ Ibid., pp. 600-607, especially, pp. 600-602.

${ }^{27}$ Ibid., pp. 601-602, 647. 
be considered a miracle or everything should be; in either case, they are all the effects of God's acting upon matter continually. And thus Clarke concludes: "There is no such thing, as what men commonly call the course of nature, or the power of nature. The course of nature, truly and properly speaking, is nothing else but the will of God producing certain effects in a continued, regular, constant, and uniform manner: which course of manner or acting, being in every moment, perfectly arbitrary, is as easy to be altered at any time, as to be reserved." 28

Nieto certainly did not require Clarke's felicitous phrasing to frame his own argument. He could enlist and did enlist the authority of Jewish luminaries from Judah ha-Levi, to Judah Moscato, to Jacob Abendana. ${ }^{29}$ Nevertheless, Nieto's text is strewn with tantalizing hints that its author may have had Clarke's arguments or those like his in mind when composing his own work. In the second dialogue, Nieto allows Reuven to respond to Simon on the need for divine miracles. Reuven's first strategy is to downplay the importance of miracles in establishing truths "rooted in the inmost recesses of our hearts". But he then argues, like Clarke, that there is no difference between the natural and the miraculous since all are engendered by the divine will. He insists that he can prove his case by not making use "of modern authorities who have power but to opin, but only of acknowledged ancients who founded dogmas and established doctrines." ${ }^{30}$ But the mere mention of "modern authorities" suggests indeed that he is familiar with their opinions. Moreover, the examples that follow appear to indicate that those modern opinions were simply too appealing to be ignored.

Nieto curiously offers the example of wheat to argue that divine providence is the sole cause of nature. He argues that naturalists assume "that Got put into the earth invisible corpus-

${ }^{28}$ Ibid., pp. 696-98.

${ }^{29}$ De La Divina Providencia, pp. 12-14; On Divine Providence, pp. 21-23.

${ }^{30}$ De La Divina Providencia, pp. 35-37; On Divine Providence, pp. 42-44. 
cules, divided and spread in a manner that they unite to the sown grain as modern atomists contend. Or it must be believed that the wheat comes invisibly from the ambient air where it is supposed to be divided into corpuscules... This formulation be conceived how it may, no understanding will be induced to believe ... that an inanimate thing like the earth can form another object superior to itself." ${ }^{31}$ He next turns to the analogy of clocks to prove his case: "Suppose a rustic who never saw clocks were to see the hands of a clock without knowing the art of the wheel or the pendulum. He will consider and declare that those metal hands have an inward virtue... He clearly confuses the effect with the cause, as those who argue that nature is the cause and not God." 32

The language of corpuscules and clocks under the aegis of God's protecting hand is unmistakably the language of Robert Boyle, a language so commonly evoked by Newtonians and other admirers of Boyle in the early eighteenth century. ${ }^{33}$ In these latter examples Nieto was not directly borrowing from Clarke to argue his case for the misuse of the term "universal nature" and for impiously attributing "power and strength to secondary causes," rather than to God. Nevertheless, Nieto and Clarke obviously shared a common intellectual agenda and a kinship of spirit. They were both admirers of Boyle and they were both in essential agreement over the need to defend a traditional view of divine providence against the dangerous implications of a notion where God and his creation were virtually separate. Nieto may have protested too loudly about his lack of reliance on modern authorities. Robert Boyle also appeared to be his hero whether he admitted it or not!

${ }^{31}$ De La Divina Providencia, p. 53; On Divine Providence, p. 55a.

${ }^{32}$ De La Divina Providencia, pp. 54-55; On Divine Providence, p. 60.

${ }^{33}$ See M. Boaz, Robert Boyle and Seventeenth-Century Chemistry (Cambridge, 1958); McGuire, "Boyle's Conception of Nature". 
Mateh Dan, Nieto's magnum opus, was published in London in 1714 and represented his most comprehensive defence of traditional Jewish faith and practice. His wide-ranging arguments in support of the Oral Law, their traditional Jewish sources, and their appropriate context of an ex-converso audience, have been properly noted by Jacob Petuchowski and need not detain us here. What is critical for our discussion is Nieto's extensive use of science to bolster the authority of the rabbis and to present effectively the virtues of the Jewish faith. Even a superficial reading of the Mateh Dan displays how seriously Nieto took the scientific context of his contemporaries. Like his Christian colleagues, the followers of Boyle and Newton, he fully acknowledged that an argument for the viability of his faith would only be credible if couched in the language of science. Judaism had to be shown to be open and willing to embrace science. Furthermore, it would have to be demonstrated how the Jewish faith might complement and enhance the moral and spiritual life of the individual particularly in areas where science might prove insufficient and incapable of penetrating. Nieto would have to preserve a precarious balance between praising science on the one hand, while simultaneously pointing out, in as gentle way as possible, its limitations and inadequacies.

Nieto devotes the fourth book of Mateh Dan to these two objectives. Alligning himself with a sizable number of earlier Jewish thinkers who had argued for the legitimacy of scientific pursuit in Judaism, Nieto eloquently presents the case that the rabbis had not only permitted studies of the natural world but excelled in them. He even points out that kabbalists like Cordovero and Herrera were not adverse to employ naturalistc arguments to explicate their theosophies. ${ }^{34}$ Nieto notes with pride how rabbinic literature is replete with learning in a variety 
of disciplines from rhetoric, to geography, to surgery, engineering, and astronomy. ${ }^{35}$ Although he admits that the rabbis were interested in the sciences only to the extent that the latter helped to clarify problems of Jewish law, nevertheless, he stresses, in strong Baconian language, that their considerable knowledge was not based on speculation but on experience. ${ }^{36}$

Having identified his empiricist leanings, he is ready to evaluate the epistemological basis of the new mechanical philosophies of his day as potentially competing with the veracity of his own religious faith. What follows is a fully informed and accurate summary of the four primary theories of the origin of matter: those of Aristotle, Gassendi, Descartes, and the chemical philosophers. He discusses the virtues and limitations of each theory and then concludes that despite their obvious rationality and consistency, they are all hypothetical. Since there are four and not one, and each claims to be the truth, he cannot view any of them as certain but only as possible, plausible explanations of reality. ${ }^{37}$ Nieto is also conversant with the claims of Copernican astronomy and those who argue for the plurality of worlds beyond the known universe. He admits the reasonableness of both theories and is willing to accept them as long as they do not contradict accepted positions of traditional faith. On the basis of the latter criterion, he approves of the second theory but must reject the first since it contradicts an explicit biblical statement. ${ }^{38}$

The speculative nature of the regnant theories of matter in the seventeenth century is not the only limitation of contemporary science. Despite the dramatic impact of recent discoveries, especially in his own day - Nieto explicitly mentions the

35 Ibid., pp. 100-123.

36 Ibid., pp. 107, 123.

37 Ibid., pp. 141-147. For the precise background for this section, see $M$. Boaz, "The Establishment of the Mechanical Philosophy," Osiris 10 (1952): 412-541.

38 Ibid., pp. 126-131. 
barometer, the thermometer, and the telescope - scientific discovery in his estimation is accidental and incomplete. ${ }^{39}$ It can never claim to understand reality in its totality. Nieto's enthusiastic endorsement of experimental science is thus tempered by a scepticism that acknowledges science as a partial but never complete truth. In light of the incompleteness of scientific achievement, there remains a place for the rabbis and the divine origin of their sacred revelation. In arguing for the compatibility of science and Judaism, and simultaneously against the claims of the self-sufficiency of science devoid of religiosity, Nieto had followed a well trodden path of Christian scientific practitioners like Mersenne and Gassendi, as well as that of a recent group of Jewish thinkers located especially in Italy. ${ }^{40} \mathrm{His}$ defense also mirrored that of Samuel Clarke who had argued quite forcefully at the end of his lecture on the truth and certainty of the Christian religion that mankind required the saving truth of Christian revelation since a mechanical understanding of the world alone was deemed insufficient. ${ }^{41}$

Nieto, in the Mateh Dan, had faced squarely and openly the challenge the new sciences presented Judaism and had devised the most effective strategies he could muster. Nevertheless, his full justification and rationale for Judaism and the oral law remained somewhat less than convincing and even a bit untidy. Faced with the formidable challenge of explaining the seemingly fantastic midrashim of the rabbis before a "sober and reasonable" audience, he could do no more than admit his inability to fathom their meaning. So he argued that although we do not yet understand the meaning of many rabbinic homilies, we continue to learn more each day about the facts of nature which will eventually confirm what presently remains unconfirmed. ${ }^{42}$

39 Ibid., pp. 148-155.

${ }^{40}$ On this, see Ruderman, "The Language of Science as the Language of Faith".

${ }^{41}$ Clarke, The Works, pp. 702-28.

${ }^{42}$ See Petuchowski's summary, pp. 99-105. 
His one attempt to explain the rabbinic bat kol [a kind of heavenly communication] as an allusion of auditory perception seems forced and specious. ${ }^{43}$ And even more problematic is his notion of the commandments. Despite a long and revered tradition of exploring the rational reasons for the divine commandments, Nieto will have no part of it. The mizvot of Judaism function like sacraments in Christianity. They are deemed holy and require no rational justification. ${ }^{44}$ Perhaps his effort to remove the commandments from the realm of all rational speculation is his way of acknowledging that any such reflections are inadequate before the critical inquiry of the new empiricism. His other arguments in support of the oral law are neither original nor fully persuasive, as Petuchowski has pointed out. ${ }^{45}$ Nieto had accepted the formidable challenge of articulating a Jewish theology in consonance with the highest standards of rationality of his day. His new defense of faith had addressed directly and passionately the intellectual demands of the new sciences. The results were mixed and less than conclusive. In the stimulating intellectual climate of Newtonian England, any rational defense of traditional Jewish faith, even as engaging and as novel as Nieto's, was to prove vulnerable and implausible to even some of his own students.

Nieto published Esh ha-Dat, a critique of Nehemiah Hiyya Hayon, only a year later in 1715 probably at the urging of his fellow colleagues Moses Hagiz and Zevi Ashkenazi who had hounded the notorious heresiarch since the beginning of his public career in Europe ${ }^{46}$ It is unclear to what degree Nieto had

${ }^{43}$ Mateh Dan, pp. 161-64.

${ }^{44}$ See Petuchowski, pp. 64-68.

${ }^{45}$ Ibid., pp. 69-98.

46 The latest reconstruction of the Hayon controversy, from the perspective of Moses Hagiz, is that of E. Carlebach, The Pursuit of Heresy, pp. 75-159. On Nieto, see especially, pp. 144-48. 
his heart in this project of heresy hunting. He must have felt obliged to respond to Ashkenazi who had come to his support during the controversy over the sermon on divine providence. Hagiz had been in London and was certainly a persuasive crusader in his own right. No doubt Nieto found the public teachings of Hayon obnoxious, even though it remains unclear to what degree he had systematically studied the latter's writings. He knew enough to make the ideological connection between Hayon and Abraham Cardoso, the disciple of the messianic pretender Shabbetai Zevi, and the architect of his own version of Zevi's messianic ideology. ${ }^{47}$ Although Nieto challenged several of Hayon's alleged pronouncements in the first part of the work, using again his familiar dialogical form, by the second part he seems to have ignored Hayon entirely to pursue other related issues of faith. As a critique of Hayon's theology, Esh ha-Dat is weak and insubstantial; as a portrait of Nieto's ultimate concerns, it is even more revealing than his other writings.

Recent scholarship on Hayon has clarified beyond a doubt that the commotion over Hayon's public appearances and writings had little to do with messianism or Shabbetai Zevi. ${ }^{48}$ He was certainly associated with the apostate messiah but the issues his detractors raised were of a different sort. Hayon was Cardoso's faithful disciple who worked to disseminate his master's teachings throughout Europe. These teachings were antiphilosophical at their core, although they were informed by philosophical knowledge. Cardoso had taught that a dualistic separation existed between the immanent first cause of the philosophers and a totally hidden and transcendent God of Israel. Hayon preached this dualism while questioning the possibility of the simple pure immanent deity known to men;

${ }^{47}$ See Carlebach, p. 98.

${ }^{48}$ I refer specifically to Leibes' essays mentioned in note 2 above and Carlebach's book. 
instead he suggested a trinitarian notion of the Godhead obviously conjuring up Christian associations in the mind of some of his critics. Hayon also advocated free inquiry and public disclosure of the most esoteric teachings of Judaism, implying that submission to rabbinic authority was unnecessary and even undesirable. $^{49}$

In his critique of Hayon, Nieto ignores Hayon's trinitarian concept, perhaps in deference to the Christian readers of his work, or perhaps because it simply did not offend him as much as another concept Hayon had championed. He faults Hayon primarily for his dualistic notion of a Jewish God who has no relation to the world and those smaller 'gods' who direct and govern the created world. ${ }^{50}$ To the readers of Nieto's treatise on divine providence, the issue was a familiar one. Hayon's dualism seemed to be yet another variation of the notion of plastic nature and such a position for Nieto was deistic. To posit a distinctly Jewish God as unconcerned and unrelated to his creation was to portray Judaism as a religion closer to paganism than to Islam and Christianity. For Nieto, a Judaism which failed to acknowledge that one God created the heaven and earth, that there was an ongoing divine providence and a system of rewards and punishments was not Judaism at all. Not only the two other major western religions but most of the civilized world shared such essential notions of faith. And why would Hayon prescribe a unique Jewish faith unrelated to either Christianity, Islam, or philosophical inquiry, asked Nieto. Surely the power of Judaism was to be located in those truths it shared with the other religions, not in holding positions which contradicted them. ${ }^{51}$ Finally, if doctrines of faith could be proven rationally, even one like transubstantiation, why was

49 See the summaries of Hayon's theosophy by G. Scholem in EJ 7: 1500-03, and by E. Carlebach, pp. 86-104.

${ }^{50}$ Esh ha-Dat (London, 1715), p. 9a.

${ }^{51}$ Ibid., pp. 15b-16b. 
this to be considered a disgrace to the Jewish people rather than a distinct virtue and advantage? ${ }^{52}$

Nieto's formulations of Hayon's faults transparently reveal the rabbi's primary motivation in attacking Hayon. For Nieto, Hayon was a deist because he understood the Jewish God to be unconcerned with and unrelated to his creation. And such deism, as Samuel Clarke had indicated, would lead ultimately to "absolute atheism". Furthermore, Hayon was a dangerous enthusiast who claimed direct inspiration from God and who sought to undermine the existing hierarchy of rabbinic authority. ${ }^{53}$ Nieto firmly believed that the rabbinate, particularly the educated rabbinate armed with the tools of modern science, was solely responsible for determining the boundaries of normal behavior. These norms, as Nieto understood them, required Jews to be sober and reasonable and self-restrained, to live within the limits imposed by both rabbinic and secular authorities. By labeling Hayon a pagan idol worshipper, Nieto placed him squarely beyond the limits of normal propriety. Nieto, the rabbi, doctor, educated in the ways of philosophy and science, had come to judge the unstable enthusiast and found his behavior dangerously unacceptable. ${ }^{54}$

If there remains any doubt about Nieto's basic fears regarding Hayon, his additional comments in the Spanish supplement to Esh ha-Dat are even clearer. ${ }^{55}$ In this writing, Nieto unambiguously expresses his credo as a public religious leader. His major objective is to gain civic acceptability for the Jewish minority living in a Christian environment. ${ }^{56}$ Jewish religious institutions can only be legitimated on the assumption that

52 Ibid., pp. 16b-17a.

53 Note Carlebach's designation of Hayon as an enthusiast, p. 89, and see the literature on enthusiasm above in note 12 .

54 My formulation here is influenced by Michael Heyd's essays on enthusiasm listed in note 12 above.

s5 See R. Loewe, “The Spanish Supplement to Nieto's 'Esh Dath" Proceedings of the American Academy for Jewish Research 48 (1981): 167-96.

56 Ibid., p. 282. 
Jews conduct themselves by the same norms the Christians do. Hayon's irresponsible pronouncements undermine the public credibility of the Anglo-Jewish community. By differentiating between a transcendent Jewish God and an immanent first cause of the philosophers, Hayon had severed the Jewish faith from a universal notion of monotheism shared by the two faiths. If God was not the first cause, He could not be unique, eternal, or omnipotent as Western monotheistic faiths grounded in reason had portrayed him. By undermining the common foundation of the two faiths, Hayon had done an injustice not only to Jewish theology but to Jewish civic acceptance and this was, in Nieto's eyes, "heregia, libertinage, atheismo." 57 By contrast, Nieto required a Jewish faith fully displaying its common principles with the dominant Christian one and validated by rational, scientific arguments. Such a faith, like that of Samuel Clarke, affirmed the stability and harmony of the social order against all radical sectarians, deists, atheists, and enthusiasts like Nehemiah Hayon.

In the second part of Esh ha-Dat, Nieto conveniently forgets the embarrassing Hayon to underscore those aspects of Judaism that Jews hold in common with the rest of civilized humanity. His points again sound like a Jewish version of Samuel Clarke's discourse, this time resembling Clarke's discourse concerning the being and attributes of God of $1704 .{ }^{58}$ Like Clarke, Nieto offers his proofs of God's existence based on conventional teleological and cosmological arguments standard for the early eighteenth century. ${ }^{59}$ We might see such parallel lines of thought between the Jewish and Christian clergyman as a mere coincidence if not for the fact that Nieto adds a seemingly innocent anecdote regarding an alleged conversation with a

${ }^{57}$ Ibid., pp. 286-89. On the term "libertinage", see Jacob, The Cultural Meaning of the Scientific Revolution, p. 45.

${ }^{58}$ Clarke, The Works, pp. 511-77.

59 They are summarized by Petuchowski, pp. 107-114. See Esh ha-Dat, 29a-31a, and Clarke, pp. 542-70. 
disbeliever who lacked a rational foundation for affirming an eternal God. Nieto prefaces this account by distinguishing between two kinds of heretics: the first, ignorant barbarians who are incapable of knowing better, and the second, who are intelligent but simply cannot comprehend God's existence without positing his beginning. The second group mistakenly attribute eternity to creation instead of to the creator. ${ }^{60}$

We might not pause to summarize such a relatively insignificant conversation if it were not for the fact that Dr. Clarke had deliberated on the same problem in a way remarkably similar to that of Nieto. Clarke begins his address by reflecting on three types of atheists. The first are wholy ignorant or stupid while the second "through habitual debauchery have brought themselves to a custom of mocking and scoffing at all religion, and will not hearken to any fair reasoning." Only the third type use speculative reasoning and can be influenced by rational argument; they alone are the subject of his remarks. ${ }^{61}$ Nieto had collapsed the first two categories into one but clearly he preserved the distinction of those atheists who were helplessly lost in their perversity and those who could be cured by the charm of persuasive logic. Having located the atheist he hoped to engage in discussion, Clarke immediately turned to the challenge of conceiving an eternal God, as opposed to an eternal matter or motion proposed by such atheists as Toland. ${ }^{62}$ Nieto's response to his heretic who struggles with the difficulty of comprehending the eternity of God is striking in its similarity to Clarke's discussion. Might Nieto have consulted Clarke's address of 1704 when composing the second half of Esh ha-Dat, and could he even have been aware of Clarke's second address published the following year in constructing his earlier argument of divine providence? Such circumstantial evidence is enticing if not compelling. Whatever the case, the parallels between Nieto's

${ }^{60}$ Esh ha-Dat, p. 31 b.

${ }^{61}$ Clarke, pp. 521-23.

62 Ibid., pp. 524-31. 
and Clarke's lines of argumentation in each of their compositions strongly recommend a common universe of discourse that both religious thinkers and communal leaders shared.

Seen as a whole, Nieto's major writings suggest a consistent and well conceived educational strategy of how to present the Jewish faith in a social environment isolated from the mainstream of Jewish culture, relatively secularized, whose attachments to traditional Jewish norms were highly attenuated. By choosing to construct his own public image of Judaism along the lines similar to the Anglican social and intellectual elite, he hoped to present the most effective case for Jewish faith and to insure the civic welfare of the Jewish community. An examination of Nieto's theology thus offers a remarkable test case of adaptation and reformulation of Judaism in the light of the formidable challenge scientific advances had posed to traditional faith.

Nieto's intellectual efforts surely left their positive impression on members of his congregation, especially on a small coterie of disciples, most of them physicians, who maintained affectionate ties with their master up until his death in 1728. Yet even Nieto's example of enlightened Jewish faith and civic virtue would prove insufficient in winning the Jewish loyalty of one of his closest associates. Some thirty years after Nieto had died, Dr. Jacob de Castro Sarmento, one of his most brilliant students and colleagues, wrote to the elders of the Spanish and Portuguese congregation announcing his intention to withdraw from the community on the grounds that "the different opinion and sentiments I have entertained long ago ... entirely dissenting from those of the Synagogue ... do not permit me any longer to keep up the appearance of a membership in your body. I therefore now take my leave of you, hereby renouncing expressly that communion in which I have been considered with 
yourselves". ${ }^{63}$ Sarmento's break with his ancestral heritage as embodied in the legacy of David Nieto adumbrated dramatically the increasing wave of such defections from traditional Judaism to follow in years to come. In the long run, even Nieto's elaborate reconstruction of Judaism, like Mendelsohn's after him, would not prove sufficient in confronting the mighty forces of Jewish social disintegration unleashed by the rapidly changing political and cultural ambience of Enlightenment and Revolutionary Europe.

${ }^{63}$ The passage is quoted in R. Barnett, "Dr. Jacob de Castro Sarmento and Sephardim in Medical Practice in 18th-Century London," Transactions of the Jewish Historical Society of England 27 (1978-80): 94. 